\title{
Innovative trends in breeding disease resistant rice varieties
}

\author{
Grigory Zelensky ${ }^{1,2, *}$, Elena Dubina ${ }^{1}$, Maxim Ladatko ${ }^{1}$, and Olga Zelenskaya ${ }^{2}$ \\ ${ }^{1}$ Federal Research Center of Rice, 350921, Krasnodar, Belozerny, Russia \\ ${ }^{2}$ Kuban State Agrarian University named after I.T. Trubilin, 350044, Krasnodar, st. Kalinina, 13, \\ Russia
}

\begin{abstract}
Rice has become widespread in world agriculture due to its high adaptation to growing conditions and the selection of many different types of varieties. The creation of new varieties of rice in Russia has been carried out using the methods of complex multistage hybridization and marker selection with close cooperation of breeders and biotechnologists. The result of this work is a mid-season variety Utyos that combines high yields with resistance to blast, the main fungal disease of rice that affects leaves, stems and panicles of the plant. The late-ripening rice variety IR36 , which has complex resistance to fungal and bacterial diseases and viruses, was used as a donor. Variety Utyos was created by selecting an elite plant from the $\mathrm{F}_{2} \mathrm{BC}_{4}$ Flagship / IR-36 population, with repeated selection and verification by offspring. Starting from the first backcrossing, marker control was carried out for the presence of transferred donor alleles in the hybrid offspring. In parallel, phytopathological control was carried out against an infectious background. In 2019, in environmental tests, Utyos formed the maximum grain yield of $11.95 \mathrm{t} /$ ha with winter wheat as the predecessor. At the same time, the variety showed high resistance to blast.
\end{abstract}

\section{Introduction}

Rice provides food for most of the world's population. It is cultivated in 114 countries under different soil and climatic conditions on an area of about 155 million hectares [1]. In 2016, global rice consumption amounted to 518 million tons (in terms of the weight of the hulled rice), showing a steady growth from 2007 to 2016 on average by $1.4 \%$ per year [2]. Experts believe that with such an annual increase in 2025, the consumption of rice in the world will reach 570 million tons. The average per capita consumption of rice is about 72 $\mathrm{kg}$ per year. Therefore, sustainable rice production is the guarantor of food security in many countries [3].

In the countries of Asia, rice is a staple food with a very high level of consumption (Myanmar - 306, Vietnam - 285, Thailand - $233 \mathrm{~kg}$ per year) [4], and for residents of European countries and the Russian Federation, rice is a valuable food, dietary and medicinal product. The rice consumption here is less than $5 \mathrm{~kg}$ of rice per year [5].

\footnotetext{
* Corresponding author: zelensky08@mail.ru
} 
The wide spread of rice in world agriculture was facilitated by the high adaptive ability of the crop through the created varieties. China is the world leader in rice production, and scientists use both traditional breeding and innovation to create varieties, using functional genomics and molecular breeding to develop high-yielding, stress-resistant rice varieties with good grain quality [6]. Practically in all large rice-producing countries, independent breeding work is underway to create varieties adapted to local conditions and cultivation technologies.

In the countries of the tropical zone, where the seedling rice culture is adopted, the highly bushy varieties suitable for this technology are created. In countries with a temperate climate like Australia, Brazil, the USA, EU countries, the Russian Federation, direct sowing of rice seeds into dry or pre-moistened soil is used [7]. Therefore, varieties are bred for such a technology.

When breeding rice varieties in different countries of the world, both general and specific requirements are highlighted depending on local conditions. General requirements include the level of yield, quality of cereals, resistance to lodging of plants and shedding of grain, easy threshing during mechanized harvesting, resistance to diseases and pests. A rice disease such as blast, caused by the fungus Pyricularia oryzae Cav., affects rice plants in almost all rice-growing regions. Therefore, breeders are actively conducting traditional and marker breeding of rice varieties that combine resistance to this disease with high yields [8, $9,10]$.

Specific requirements vary depending on the growing conditions of the crop. In countries with a temperate climate, the growing season, early maturity of the variety, resistance to low positive temperatures, salt tolerance, and resistance to air drought during grain filling are of decisive importance [11]. The latter is especially important for rice varieties grown in Russia [12].

In countries with a tropical climate, where rice is affected by numerous diseases caused by viruses and bacteria, the selection of varieties resistant to such pathogens with an improved genotype becomes of paramount importance [13, 14].

Historical analysis of rice breeding in different countries shows that it has been carried out according to the same scheme: Introduction $\rightarrow$ Analytical breeding $\rightarrow$ Synthetic breeding [15]. In this case, hybridization, mutagenesis, various methods of biotechnology, assessment and selection of breeding material against infectious and provocative backgrounds are used [16, 17].

While spreading rice to new growing areas, introduction was important. Japanese and Italian rice varieties introduced to Russia became the basis for most varieties created by Russian breeders [18]. So, growing the Japanese variety Kenzo at the beginning of the twentieth century began in the Far East, and then in the 1930-ies it was brought to the Krasnodar Territory. For 20 years, Kenzo was the main cultivated variety in this area. At the same time, Kenzo was widely used in hybridization as the donor of early maturity.

The Italian short-stem salt-tolerant cultivar Balilla grano grosso, in 1966 was brought to the world collection of the All-Russian Institute of Plant Genetic Resources named after N.I. Vavilov (St. Petersburg), and then included in the hybridization at the All-Russian Research Institute of Rice (now the Federal Research Center of Rice). As a result, a number of short-stem rice varieties with increased salt tolerance were created: Spalchik, Pearl, Kulon, Aprelsky, Privolny, Primorets, Vevel, Regul, Kurchanka, Leader, etc. [18]. The Spalchik variety [Balilla grano grosso x (Krasnodar 3352 x Kendzo)] was cultivated in the USSR in the 1980-ies on an area of more than 250000 hectares. The rice variety Leader has become widespread not only in the Russian Federation, but also in the Republic of Kazakhstan, currently occupying more than $75 \%$ of the rice sown area there [19]. 
Intraspecific and interspecific hybridization, followed by selection and evaluation of offspring against special backgrounds, marked the beginning of synthetic breeding. As known hybridization includes castration (removal of anthers) and pollination.

Different methods of anther removal are used in the rice breeding: with tweezers, a needle, squeezing, applying heat shock (hot water, steam, high frequency currents), as well as chemical castration. However, the ovary formation of hybrid grains with these methods does not exceed 25-30 \%. Russian breeder G.D. Los (2007) after having verified that these methods are ineffective for mass hybridization, developed a modern technology for rice hybridization, including cutting off the top of the spikelet, removing the anthers with a vacuum compressor at a temperature of $20-22{ }^{\circ} \mathrm{C}$ and pollination using the Twell-method. The use of this technology made it possible in the Federal Research Center of Rice to raise the ovary formation of hybrid grains up to $50-60 \%$, and in some variants up to $90 \%$ [20]. Hybridization is carried out all year round, using artificial climate chambers. This technology allows crossing parental forms with different vegetation periods and obtaining the required amount of hybrid material. These tools have significantly improved breeding results [21].

In some cases, intraspecific hybridization does not solve the problem of resistance to individual pathogens. So, among the cultivated rice samples, there was no donor of resistance to the dwarf virus that destroys rice crops in the tropical zone. This problem was solved by G. Khush, the leading breeder of the International Rice Research Institute (IRRI). He performed hybridization of cultivars of the cultivated species Oryza sativa L. and the related wild species Oryza nivara Sharma et Shastry, the latter was the donor of resistance to blast and dwarf virus. The IR-36 rice cultivar created as a result of complex stepwise hybridization possessed complex resistance to fungal and bacterial diseases and viruses [22]. IR-36 has become very popular among tropical farmers. In addition, the IR-36 variety is used as a parental form in many countries including Russia when breeding new varieties.

With contemporary traditional rice breeding, it takes 12-15 years to create a variety. Such a long period is associated with the implementation of the entire cycle of work according to the scheme of the selection process, where at each stage the best material is selected and the genotype of the selected plants, forms, samples is homozygous. The created rice variety must be homozygous for almost all traits. Methods of biotechnology help to speed up the breeding process [23], especially when creating varieties resistant to diseases.

In general, at the present stage, rice breeding in the leading rice growing regions of the world is successfully carried out with the use of innovative biotechnologies, which make it possible to create optimal genotypes of highly productive rice varieties and hybrids resistant to unfavorable environmental factors [3, 24].

\section{Materials and research methods}

When carrying out breeding studies, there were used basic techniques refined in accordance with the task and the use of small-sized equipment. Soil preparation and crop cultivation was done taking into account the recommendations for rice cultivation adopted for the area. The water regime was maintained according to the shortened flooding option.

The original breeding material was created by intraspecific hybridization, including complex multistage crosses and backcrosses [21].

The donor of the transferable blast resistance gene Pi-ta, localized on the second chromosome, was the Asian rice cultivar IR-36, which was crossed with the recipient domestic mid-ripening rice cultivar Flagman. During plant hybridization, pneumatic castration of maternal forms and pollination by the twell-method were used [20]. 
To identify the donor allele, a molecular marker with specific primer pairs was used, showing the greatest allelic difference in the length of microsatellite repeats between the parental forms. It was created jointly with the laboratory for the analysis of the genome of FSBRI "All Russian Research Institute of Agricultural Biology" [25]

The resulting hybrid plants were grown in vessels on a growing plot (2007-2011). For molecular genetic studies, green rice leaves were selected, and genomic DNA was isolated from them in the laboratory of Federal Research Center of Rice, according to the manufacturer's instructions. PCR products were separated by electrophoresis in $8 \%$ acrylamide gel.

The offspring of the isolated elite plants were studied according to the breeding process scheme, including assessment against an infectious background (2012-2018) [16].

The experimental data were statistically processed using Excel and Statistica 6 software.

\section{Research results}

The creation of infectious nurseries to assess breeding material for disease resistance has significantly increased the efficiency of breeding new rice varieties. A large quantity of hybrid seeds made it possible to sow them in an infectious nursery where unaffected plants were selected against the background of artificial infection with $P$. oryzae. As a result, more than 20 varieties of rice with high resistance to blast disease not requiring chemical protection from the disease have been bred.

In modern breeding for resistance to rice diseases, along with simple crosses, complex stepwise hybridization and backcrosses are widely used. This expands the ability to include resistance genes from different donors into the cultivar's genes. An illustrative example of the use of complex hybridization in breeding rice varieties that combine high yield with resistance to blast is the variety Gamma (Fig. 1).

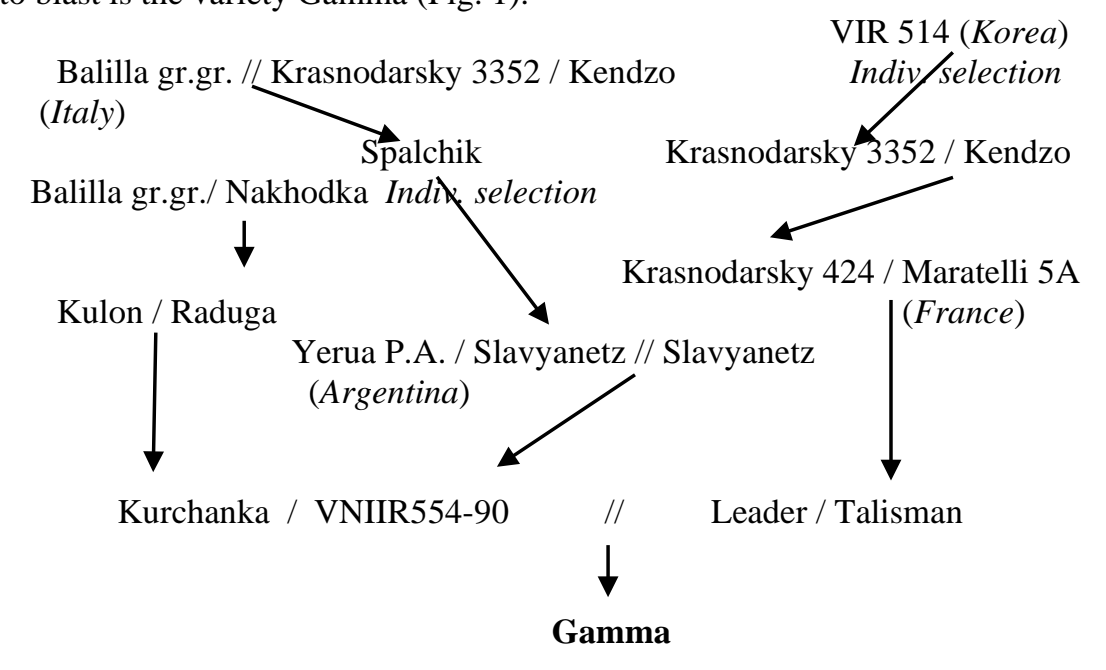

Fig. 1. The pedigree of the rice variety Gamma [21]

At the Federal Research Center of Rice, breeders and biotechnologists are carrying out a joint breeding program for blast resistance. In this case, modern biotechnological approaches (molecular labeling) are used [26, 27]. The use of specialized DNA markers associated with disease resistance provides a clear control of the inheritance of the target locus. This helps to reduce the time and material costs in modeling and creating a promising genetic plasma [28]. The result of this work is the creation of a new variety of 
rice Utyos obtained by individual selection from $\mathrm{F}_{2} \mathrm{BC}_{4}$ Flagman / IR-36, with repeated selection and verification of offspring.

The donor variety IR-36 in the Krasnodar Territory turned out to be late ripening, with a growing season of more than 150 days. Rice varieties should be ripened in no more than 125 days to be grown in this area. The resulting $F_{1}$ hybrid plants had high sterility (95\%) and a growing season of 138-145 days. Therefore, it was clear that it was necessary to carry out backcrosses with the recipient parental form (Flagman) and conduct biotechnological control over the presence of the target gene in hybrid plants.

Considering the late maturity of the material obtained, all the work was carried out under controlled conditions in artificial climate chambers. During 2008, $\mathrm{BC}_{1}$ and $\mathrm{BC}_{2}$ generations were received. In $\mathrm{BC}_{1}$-populations, fertility increased and averaged about $50 \%$. In subsequent generations, fertility has steadily increased.

Starting from the first backcrossing, marker control was carried out for the presence of transferred donor alleles in the hybrid offspring. In 2009, plants of $\mathrm{BC}_{3}$ and $\mathrm{BC}_{4}$ generations were obtained. Among these plants, the forms with the shortest growing season and the highest panicle fertility were selected. From stage $\mathrm{BC}_{4} \mathrm{~F}_{1}$ (the first self-pollination of rice plants, which makes it possible to transfer the donor allele to a homozygous state), individual selection was carried out. In each generation, plants were selected that were closest in morphotype to the recipient parental form of Flagman and had a donor gene for resistance to the pathogen $P$. oryzae in a homozygous state in their genotype [15].

Figure 2 shows the results of PCR analysis for identification of the blast resistance gene $\mathrm{Pi}$-ta in the $\mathrm{BC}_{4} \mathrm{~F}_{3}$ hybrid material.

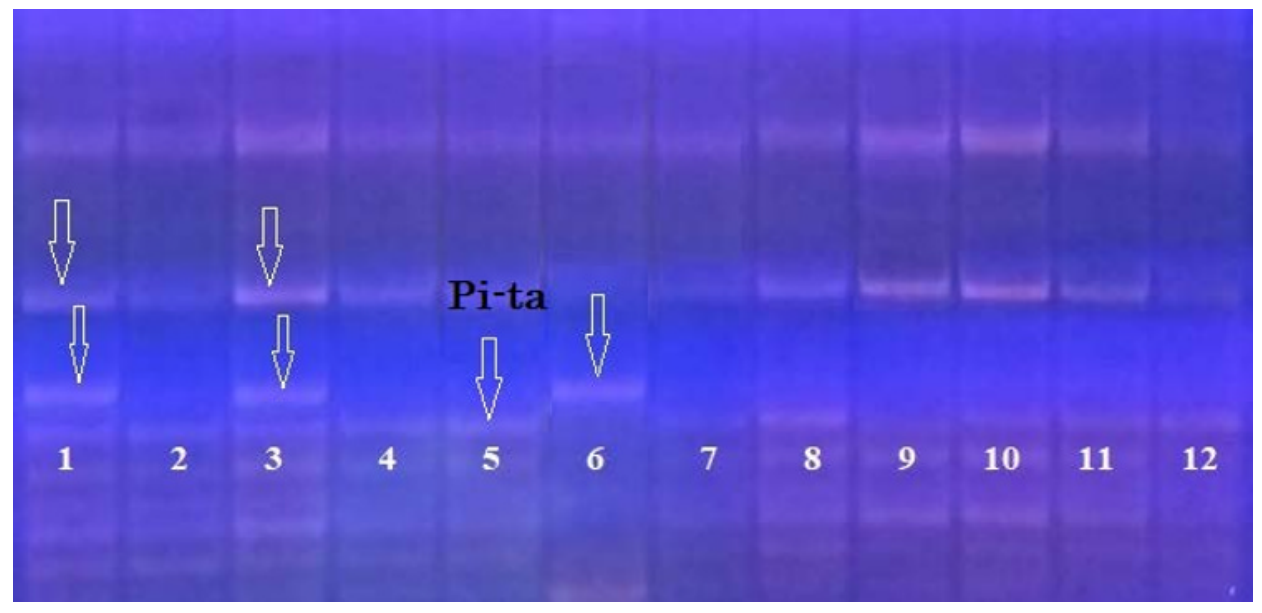

Fig. 2. Electrophoregram of genomic DNA amplification products at the Pi-ta locus: $1 . .4,7 \ldots 12$ analyzed hybrid plants of generation $\mathrm{C}_{4} \mathrm{~F}_{3}, 5$ - IR-36, Pi-ta gene donor, 6 - Flagman, maternal form.

The 52 best plants selected according to the results of DNA analysis, with the Pi-ta blast resistance gene, were studied in the field for economically valuable traits. At the same time, the progeny of these plants underwent annual phytopathological testing for resistance to blast in an infectious nursery.

According to the results of a comprehensive assessment, the sample Bio-575 was brought to a variety and under the name Utyos was transferred to the State variety testing in 2018. A brief description of this variety follows.

The awnless rice variety Utyos belongs to the species $O$. sativa, subspecies japonica, botanical variety italica Alef. The plant height is $90 \mathrm{~cm}$. Panicles are erectoid when they 
appear and medium-drooping during grain ripening, with an average length of $16.6 \mathrm{~cm}$, well-grained (176 spikelets), with low sterility (4.2\%).

Utyos belongs to the group of mid-maturing varieties, with a growing season of 117 days (an average of three years). Over the years of competitive testing, the Utyos variety showed a yield of $8.98 \mathrm{t}$ / ha with high stability over the years, which is $0.52 \mathrm{t} /$ ha higher than the standard Flagman variety (Table 1).

The Utyos variety is resistant to lodging, does not crumble, but threshes easily. It can be kept in the field after maturing and harvested by direct combining.

According to the technological assessment of quality, the grain of the Utyos variety is elongated and of medium size. Length to width ratio ( $\mathrm{l} / \mathrm{b})$ is 2.5 . The mass of 1000 grains is $29.7 \mathrm{~g}$. The average yield of cereals for three years is $71.5 \%$, including $85.1 \%$ of the whole kernel. Glassiness is $96.3 \%$. The groats are of excellent quality, with high culinary characteristics.

Table 1. Characteristics of the rice variety Utyos (Bio-575) in comparison with the Flagman variety (competitive tests, 2016 - 2018)

\begin{tabular}{|c|c|c|}
\hline \multirow[t]{2}{*}{ Characteristics } & \multicolumn{2}{|c|}{ Variety } \\
\hline & Utyos & Flagman (standard) \\
\hline Yield, t / ha & 8,98 & 8,46 \\
\hline Vegetation period, days & 117 & 119 \\
\hline Plant height, $\mathrm{cm}$ & 90 & 92 \\
\hline Panicle length, $\mathrm{cm}$ & 16,6 & 16,8 \\
\hline Spikelets per panicle, pcs. & 176 & 152 \\
\hline Density of the panicle, pcs / cm & 10,6 & 9,0 \\
\hline Sterility of spikelets, \% & 4,2 & 9,7 \\
\hline Length / width ratio (l / b) & 2,5 & 2,4 \\
\hline Weight of 1000 grains, g & 29,7 & 28,8 \\
\hline Filminess, \% & 18,5 & 19,6 \\
\hline Glassiness, \% & 96,3 & 89,0 \\
\hline The total yield of cereals, \% & 71,5 & 71,4 \\
\hline incl. whole kernel, \% & 85,1 & 81,7 \\
\hline $\begin{array}{l}\text { The incidence of blast disease, \% } \\
\text { (artificial infection *) }\end{array}$ & 17,8 & 46,5 \\
\hline
\end{tabular}

Plants of the Utyos variety are distinguished by high field germination, fast growth rates during the period of germination and increased resistance to blast in case of artificial infection. In the field, the variety was not affected by the disease over the years of study. Therefore, it can be grown without the use of fungicides and yield environmentally friendly and cost-effective high-quality products.

To increase the efficiency of the creation of varieties and to determine their adaptive properties, the Federal Research Center of Rice made a decision to carry out an mandatory ecological tests of the variety before submitting it to the State Test and to develop elements of varietal agricultural technology.

The purpose of ecological variety trials is to form rice varietal complexes for agricultural landscape regions of the Krasnodar Territory, optimize the varietal structure of crops in rice farms and select varieties that ensure the realization of their biological potential under production conditions by studying them in different soil and climatic conditions for different predecessors and rates of mineral fertilizers.

The new variety Utyos was studied under different ecological conditions of the ricesowing area of the Krasnodar Territory. In 2019, the assessment was carried out simultaneously after three predecessors: rice, winter wheat and alfalfa. In this case, two levels of mineral nutrition were used: the $1^{\text {st }}$ is background - the standard adopted in the 
farm for each predecessor; the $2^{\text {nd }}$ - top dressing $N_{30}$ was added to the background at the phase of 3 leaves of the rice plant (Table 2).

As can be seen from Table 2, the varieties formed a different yield on the three studied predecessors. Traditionally in rice growing, alfalfa is considered the best precursor for rice. The data obtained in our experiments, on the whole, did not confirm this statement. The melioration state of the rice paddies was of decisive importance. So, in the Elite Seed Experimental Station «Krasnaya» of the Krasnoarmeisky district on meadow-chernozem soil, the variety Rapan showed the best result after winter wheat placed on a high leveled ground with well-drained soil. The second most effective predecessor was alfalfa. The worst predecessor was rice. However, according to its predecessor, the yield of the rice variety Utyos exceeded Rapan, the standard variety, in both variants by 0.91 and $0.61 \mathrm{t} / \mathrm{ha}$, respectively.

Table 2. Yield of the rice variety Utyos in the ecological test in comparison with the standard Rapan variety, t / ha, 2019

\begin{tabular}{|c|c|c|c|c|c|c|c|}
\hline \multirow[b]{2}{*}{ Variety } & \multicolumn{2}{|c|}{ Rice } & \multicolumn{2}{|c|}{ Winter wheat } & \multicolumn{2}{|c|}{ Alfalfa } & \multirow[b]{2}{*}{ average } \\
\hline & $\begin{array}{l}\text { back- } \\
\text { ground }\end{array}$ & $\begin{array}{l}\text { back- } \\
\text { ground } \\
+N_{30}\end{array}$ & $\begin{array}{l}\text { back- } \\
\text { ground }\end{array}$ & $\begin{array}{l}\text { back- } \\
\text { ground } \\
+N_{30}\end{array}$ & $\begin{array}{l}\text { back- } \\
\text { ground }\end{array}$ & $\begin{array}{l}\text { back- } \\
\text { ground } \\
+N_{30}\end{array}$ & \\
\hline \multicolumn{8}{|c|}{ Elite Seed Experimental Station «Krasnaya», Krasnoarmeysky region } \\
\hline $\begin{array}{c}\text { Rapan } \\
\text { (standard) }\end{array}$ & 7,18 & 7,87 & 10,30 & 10,13 & 8,53 & 9,71 & 8,95 \\
\hline Utyos & 8,09 & 8,48 & 8,67 & 7,21 & 8,05 & 9,29 & 8,30 \\
\hline $\mathrm{HCP}_{05}$ & 0,326 & 0,224 & 0,378 & 0,363 & 0,228 & 0,232 & - \\
\hline \multicolumn{8}{|c|}{ «Lux-Agro R» LLC, Abinsk region } \\
\hline $\begin{array}{c}\text { Rapan } \\
\text { (standard) }\end{array}$ & 9,47 & 10,23 & 9,13 & 10,66 & 5,90 & 5,19 & 8,43 \\
\hline Utyos & 9,11 & 10,02 & 10,61 & 11,95 & 6,36 & 7,14 & 9,20 \\
\hline $\mathrm{HCP}_{05}$ & 0,368 & 0,327 & 0,279 & 0,264 & 0,288 & 0,272 & - \\
\hline
\end{tabular}

In «Lux-Agro R» LLC of the Abinsk region on heavy merged chernozems, the rice variety Utyos showed a higher yield than Rapan after winter wheat and alfalfa. After the predecessor rice, both varieties gave almost equal yields. The maximum yield of 11.95 $\mathrm{t}$ / ha was formed by the variety Utyos in the Abinsk region after winter wheat in the variant with top dressing $\mathrm{N}_{\mathbf{3 0}}$. The obtained data confirm the high yield potential of the new rice variety.

The results of the ecological test make it possible to recommend expanding the study of the new rice variety Utyos, especially in the production conditions of the Abinsk district of the Krasnodar Territory.

\section{Conclusion}

As a result of a combination of methods of traditional breeding and molecular labeling, the Federal State Budgetary Scientific Institution "Federal Research Center of Rice” created the new mid-maturing rice variety Utyos, capable of forming a yield of more than $11 \mathrm{t} /$ ha and having a high resistance to blast. 


\section{References}

1. FAO. Crop Prospects and Food Situation - Quarterly Global Report, 2 (Rome, 2015)

2. https://www.indexbox.ru

3. S. Pandey, D. Byerlee, D. Dawe, A. Dobermann, S. Mohanty, S. Rozelle, B. Hardy. Rice in the Global Economy: Strategic Research and Policy Issues for Food Security (IRRI, 2010)

4. G. Bishwajit, S. Sarker, M.A. Kpoghomou, et al., Agric \& Food Secur, 2, 10 (2013)

5. G.L. Zelensky, O. V. Zelenskaya, Scientific journal of the KubSAU, 08 (72), 01 (2011) http://ej.kubagro.ru/2011/08/pdf/01.pdf

6. S. Bai, H. Yu, B. Wang, J. Li, J. Genet. Genom. 45, 11, 603-612 (2018)

7. H. Farooq, Soil and Tillage Research, 111, 2, 87-98 (2011)

8. M. Khan, Z. Dar, S. Dar, Agricultural Sciences, 6, 467-478 (2015)

9. Y. Deng, K. Zhai, Z. Xie, D. Yang, X. Zhu, J. Liu, X. Wang, P. Qin, Y. Yang, G. Zha ng, et al. Science, 355, 962-965 (2017)

10. E. Dubina, P. Kostylev, M. Ruban, S. Lesnyak, E. Krasnova, K. Azarin, Plants, 9, 113 (2020)

11. K.I. Cordero-Lara, Chil. j. agric. res., 80, 2, 303-314 (2020)

12. S. Garkusha, O. Zelenskaya, G. Zelensky, Proceed. VII ITRC, 161-165 (Brasília, DF: Embrapa, 2020)

13. T.R. Sharma, A.K. Rai, S.K. Gupta, J. Vijayan, B.N. Devanna, S. Ray, Agric Res, 1, 37-52 (2012)

14. M. Zhang, S. Wang, M. Yuan, Mol. Breeding 39, 154 (2019)

15. A.G. Lyakhovkin. Rice. World production and gene pool (St. Petersburg, 2005)

16. G.L. Zelensky, Risovodstvo (Rice growing), 3-4 (28-29), 13-16 (2015)

17. E.V. Dubina, V.N. Shilovsky, G.L. Zelensky, E.S. Kharchenko, M.G. Ruban, S.V. Garkusha, L.V. Esaulova, Achievements of science and technology of the agroindustrial complex (Dostizheniya nauki i tekhniki APK), 29, 12, 40-42 (2015)

18. V.N. Shilovsky, E.M. Kharitonov, A.Kh. Sheujen, Rice of Russia (2002)

19. G.L. Zelensky, O. V. Zelenskaya, Scientific journal of the KubSAU, 07 (71), 06 (2011), http://ej.kubagro.ru/2011/07/pdf/06.pdf

20. G.L. Los, Risovodstvo (Rice growing), 10, 42-51 (2007)

21. G.L. Zelensky, N.N. Malysheva, I.N. Chukhir, A.G. Zelensky, A.R. Tretyakov, Proc. KubSAU, 2 (23), 89-95 (2010)

22. G.S. Khush, J. Genet., 66, 3, 195-216 (1987)

23. T.L. Korotenko, E.G. Savenko, Risovodstvo (Rice growing), 3 (48), 6-13 (2020)

24. J.D. Peleman, J.R. van der Voort, Trends Plant Sci. 8, 330-334 (2003)

25. I.A. Shilov, O. S. Kolobova, Yu.B. Aniskin, T.B. Shalaeva, H. S. Belishaeva, П. I. Kostylev, E.B. Dubina, Achievements of science and technology of the agro-industrial complex (Dostizheniya nauki i tekhniki APK), 8 (30), 45-48 (2016)

26. B. Lievens, B.P. Thomma, Phytopathology, 95, 12, 1374-1380 (2005)

27. S. Ashkani, M.Y. Rafii, M. Sariah, Genet. Mol. Res., 10 (3), 1345-1355 (2011)

28. E.V. Dubina, Z.M. Mukhina, E.M. Kharitonov, V.N. Shilovskiy, E.S. Kharchenko, L.V. Esaulova, N.N. Korkina, E.P. Maximenko, I.B. Nikitina, Russ. J. Genet., 51, 8, 752-756 (2015) 